Pregledni naučni članak

UDK: 61(091)(436)

ID: 202542860

Zdenko Samaržija

Osijek, Republika Hrvatska

zdenko.samarzija@gmail.com

\title{
HABSBURŠKO VOJNO ZDRAVSTVO U SLAVONIJI I SRIJEMU \\ DO UKIDANJA VOJNE KRAJINE
}

Apstrakt: Autor problematizira nastanak i razvoj vojnoga zdravstva u Slavoniji i Srijemu, koje se nije obaziralo na razdjelnicu na civilni i vojni dio toga područja. Kronološki i strukturalno pojašnjava uzroke nastanka Sanitarnoga kordona unutar sustava Vojne krajine i objašnjava etape razvoja humane i animalne medicine, apotekarstva i javnozdravstvenih službi.

Ključne riječi: socijalne službe, medicina, veterinarstvo, ljekarništvo Ne MeSH: Vojna krajina

Keywords: social services, medicine, veterinary, pharmacy Non MeSH: Military Frontier

Habsburšku vlast u Baranji, Slavoniji i Srijemu, koja je trajala od konca XVII stoljeća do 1918. godine, do svršetka Prvoga svjetskoga rata, obilježile su stalne promjene, pa i turbulentne, što se nije pozitivno odrazilo na društveni razvoj, osobito razvoj gospodarstva. Isprva su Habsburgovci podredili Slavoniju i Srijem upravi vojske (Vojnokomorska uprava sa sjedištem u Osijeku), no već početkom XVIII stoljeća postojale su naznake vojnoga dijela u Posavini, a civilnih oblika upravljanja u središnjim i podunavsko-podravskim dijelovima Srijema i Slavonije. Premda je u Bačkoj i Baranji 
prevladavalo hrvatsko stanovništvo, postale su te regije integralni dio Ugarskoga Kraljevstva - dio Bačke naslonjen na obalu Tise priključen je Vojnoj krajini jer je Banat još neko vrijeme ostao u rukama Turaka. Sredinom XVIII stoljeća Slavoniju i Srijem podijelili su Habsburgovci na:

- Militarili Vojnu krajinu, koja je bila podijeljena u Petrovaradinsku pukovniju sa sjedištem u Srijemskoj Mitrovici, Brodsku pukovniju sa sjedištem u Vinkovcima, i Gradišku pukovniju sa sjedištem u Staroj Gradiški, a kasnije u Novoj Gradiški - pukovnije su se dijelile u okruge ili satnije (kumpanje ili kompanije)

- Paoriju ili civilni dio, koji je bio podijeljen u Virovitičku županiju sa sjedištem u Osijeku, Požešku županiju i Srijemsku županiju sa sjedištem u Vukovaru. Županije su dijelile u vlastelinstva kojima su upravljali plemići; kasnije su se, neovisno od vlastelinstava, županije dijelile na podžupanije ili kotare. [1]

Kirurzi-ranarnici i vojni liječnici dolaze u Viroviticu, Požegu, Osijek i Petrovaradin s habsburškom vojskom, a vjerojatno su s njima, ili netom iza njih, došli i prvi ljekarnici - mnogi kirurzi i liječnici bili su redovnici-laici i klerici. U Petrovaradinu, Osijeku, Virovitici i Požegi bili su stacionari za ranjene i oboljele habsburške vojnike. Kako je fronta odmicala prema istoku i prema Savi, gasili su se vojni stacionari i pomicali bliže bojišnici; vrlo oprezno možemo pretpostaviti, u Pakracu i Iloku, gdje je bilo strateških razloga za gradnju hospitalnu vojnu infrastrukturu. Neki su kirurzi ostali u gradovima i organizirali pozadinsku zdravstvenu službu, osobito ako se zadržala komanda ili komora, ili se demobilizirali te težili k sreći u slavonskim, baranjskim i srijemskim gradovima. Poput ostalih obrtnika, čim ih je bilo nekoliko, kirurzi su udružili i potpomagali. [2-5]

Nije poznato gdje se nalazila bolnica u Virovitici - možda ima istine u predaji da se bolnica nalazila u nekadašnjim samostanima, franjevačkom i dominikanskom, koje su Turci prilagodili militarnim potrebama i potrebama saraja. [6, 7] Bolnica u Požegi bila je pored Kamenitih vrata u nekom prostoru na kat naslonjenom na gradski bedem prilagođenom za potrebe bolnice. Djelovala je do (najkasnije početka) 1698. Godine, kada se u nju naseljavaju isusovci, a da je bila prostrana svjedoči i to što su isusovci u njoj pokrenuli nastavu za tridesetak učenika. [8] Petrovaradinska bolnica, zapravo golem sklop drvenih paviljona na lokalitetu Las, zabilježila je u jednom trenutku 1692. godine 3000 pacijenata, s opaskom da se ranijih godina 
u petrovaradinskoj bolnici liječilo u isto vrijeme i 5000 vojnika. Gradnja bolnice koštala je astronomskih 52.258 forinti, a podignuta je zalaganjem i potporom kardinala Kolonića. Gradnja današnje petrovaradinske utvrde počela je 18. listopada 1692. pod zapovjedništvom Matije Kaiserfelda. [9, 10] Prva osječka bolnica bila je u nekadašnjoj medresi pokraj Kasim-pašine džamije, na mjestu gdje je danas crkva Svetoga Mihovila. [11]

Osim brige o zdravlju vojnika, prvi vojni kirurzi su pružali pomoć i građanima. U Osijeku je 1694. godine zabilježen prvi porod carskim rezom, što nije mogla izvesti primalja već samo obrazovan liječnik ili vješt kirurg. Iz 1698. godine potječu prvi podaci o održavanju higijene osječkih ulica i načinima skrbi za ratne udovice i siročad. [11]

Osijek je još u srednjem vijeku imao velik utvrđen prostor čiji je raster ulica vidljiv i danas i ne čudi što su Habsburgovci odredili Osijek za vojno središte novoosvojenih podunavskih područja. Ubrzo su porušene osmanlijske građevinske prilagodbe srednjovjekovne osječke utvrde, osobito sakralne, i počela je gradnja današnjih bedema-bastiona i drugih vojnih objekata. Gradnja tvrđavske infrastrukture završena je 1721. godine. [11]

Vojna bolnica u osječkoj Tvrđi građena je između 1726. i 1730. godine na zapadnoj strani Tvrđe u Glavnoj ulici. Bila je to uzorna Vojna bolnica smještena u raskošnoj zgradi sa dva krila, u kojoj je nekoć stanovao turski dizdar i koja je do devedesetih godina XX stoljeća odgovarala vojnohospitalnoj svrsi. U njoj su pomoć pružali i civilima nastanjenim u Tvrđi, osobito u dobu epidemija.

Vojna ljekarna u osječkoj Tvrđi stajala je nasuprot ulaza u Vojnu bolnicu, na južnoj strani iste ulice. Pored nje je bila nadaleko čuvena gostionica Kbijelom vuku. Osječka ljekarna je uvoznim lijekovima opskrbljivala vojne, civilne i dijelom redovničke ljekarne Slavonije, Baranje i Srijema - Vojna ljekarna preselit će se u bolničku zgradu 1874. godine. $[3,4,12]$

Kao kuriozitet možemo navesti da su Paulusa Sirmegha ubili razbojnici 15. listopada 1717. godine dok se iz Batine vraćao u Osijek. Bio je voditelj osječke vojne ljekarne, provisor apothecae bellicae. Pokopan je u kripti crkve Svetoga Mihovila. [13, 14]

Civilnih bolnica nije bilo, a nisu bile ni potrebne. Doktori medicine rijetko su navraćali u Slavoniju, ako izuzmemo Osijek, a još se rjeđe zadržavali u našim krajevi- 
ma. Medicinska tehnologija bila je skromna, farmaceutskih proizvoda industrijske proizvodnje nije bilo, osobito ne preparata za urgentno davanje ni tekućina koje se daju intravenozno i nije bilo potrebe da stanje oboljelih danonoćno prate medicinski djelatnici. Obitelji su brinule za oboljele članove obitelji, viši kler i redovnici su imali vlastitu medicinsku skrb (katoličkog dijecezanskoga svećenstva nije bilo do sredine XVIII stoljeća na područjima Zagrebačke biskupije, odnosno druge polovice XVIII stoljeća na području Pečuške biskupije i području Srijemske biskupije; pastoral su obavljali franjevci i isusovci - o pravoslavnom parohijskom svećenstvu brinule se njihove obitelji), a u dobu ratova nicale su velike privremene bolnice ili su ranjeni i bolesni vojnici smješteni u samostane. Beskućnici, duševni bolesnici, profesionalni prosjaci i ini pripadnici marginalnih skupina imali su bolničku skrb u ksenodohiju - ksenodohije su vodili franjevci. U Majuru, podgrađu Petrovaradinske utvrde, sagrađen je ksenodohij, što pokazuje kako je Petrovaradin, kao i Osijek i Požega, odmah po uspostavljanju habsburške vlasti privukao mnoge seljake, trgovce i obrtnike. Za napuštenu djecu građena su sirotišta, o kojima su financijski skrbili gradski magistrati, plemstvo i klerikalne udruge, a vodili ih franjevci. [6, 8, 12, 14-20]

Sanitarni kordon nije nastao odjednom.UXV stoljeću uočile su mletačke i dubrovačke vlasti nisku higijensku razinu Osmanlijskoga Carstva, te su koncem XVI stoljeća osnovali lazarete na skalama - graničnim prijelazima - te tako nadzirale trgovinu, ali i širenje bolesti iz Osmanlijskoga Carstva. Girolamo Fracastoro (1483-1553) idejni je začetnik sanitarnih kordona. Osim što je izvanredno opisao sifilis, izdao je knjigu $O$ zarazi $i$ zaraznim bolestima. Smatra da se zarazne bolesti prenose klicama i to dodirom, predmetima ili zrakom na manje udaljenosti, $i$ da je prevencija jedina učinkovita borba protiv zaraznih bolesti. Osobnom i javnom higijenom, osobito pokapanjem mrtvih te dezinfekcijom i izolacijom oboljelih, spriječit će se ulazak klica u organizam.

Poučeni njihovim iskustvima, habsburške su vlasti još u XVI stoljeću organizirale sanitarne službe, u XVII stoljeću donijele i nekoliko zakona - oni će biti osnovica sanitarnoga zakonodavstva Vojne krajine u XVIII stoljeću. Carski patent o zaštiti od kuge (1710) dao je Dvorskoj sanitetskoj komisiji glavnu riječ na polju zdravstva u Vojnoj krajini, ali i bio osnovica za donošenje niza uredbi kojima se od 1713. do 1728. godine uređuje kužni red i uspostavlja trajna protuepidemijska zaštita duž granice prema Osmanlijskom Carstvu - a ona je bila duga približno 1900 kilometara i protezala se od Karpata do Jadrana. [20, 5] Na ovom mjestu možemo navesti i odredbu iz Patenta cara Karla VI kojim je osnovan Sanitarni kordon 22. listopada 
1728. godine „Nasuprot turskim područjima treba zbog neposredne opasnosti od zaraznih bolesti urediti stalnu protuobranu prilagođenu prema težini okolnosti.“

Slavonska sanitarna komisija osnovana je 1730. godine. Sjedište joj je bilo u Osijeku, a obuhvaćala je područja od Petrovaradina duž Dunava do Zemuna pa Savom do ušća Une u Savu kod Jasenovca te do zapadnih međa Virovitice, odnosno obuhvatit će cijelu Slavonsku vojnu krajinu, to jest Petrovaradinsku, Brodsku i Gradiščansku pukovniju, te područja Srijemske, Požeške i Virovitičke županije. Od 1756. godine Slavonska sanitarna komisija podređena je Sanitarnoj komisiji Banske Hrvatske koja obuhvaća sve kontumce prema Osmanlijskom Carstvu od Zemuna do Senja. $[20,5]$

Slavonski generalat dio je Vojne krajine i bio je podređen isprva Ratnom vijeću u Grazu, a od 1743. godine Dvorskom ratnom vijeću u Beču. Osnovan je 1701. godine i u početku imao je sjedište u Osijeku. Između 1783. i 1792. sjedište ujedinjenih Slavonske generalkomande i Banatske generalkomande iz Temišvara bilo je u Petrovaradinu. Nakon razdvajanja zapovjedništvo je ostalo u Petrovaradinu, a od 1848. godine do ukidanja Vojne krajine u Zagrebu. [20]

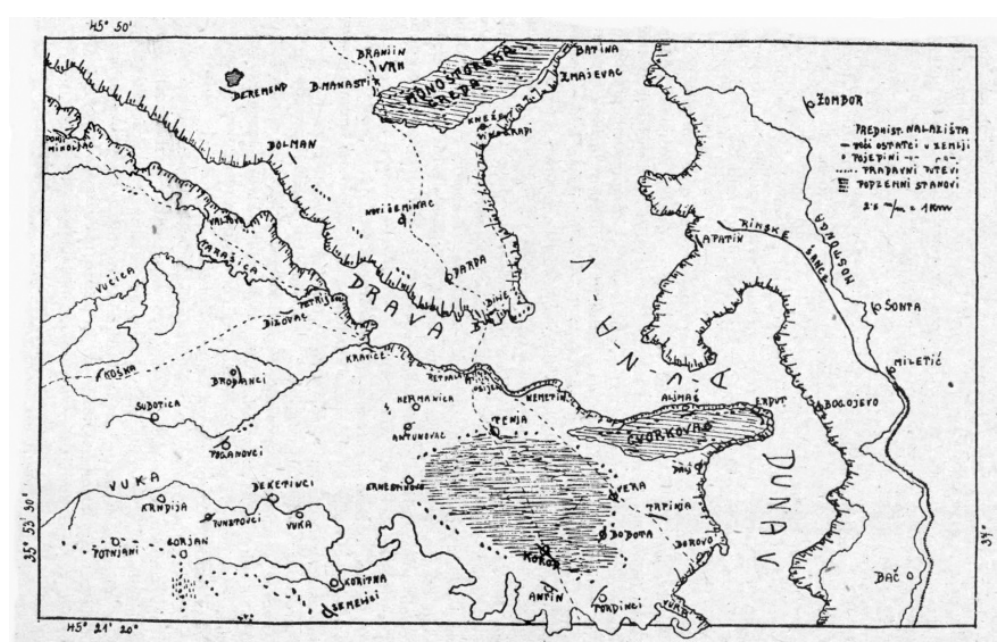

Slika 1 Prije regulacija Dunava i Drave u prvoj polovici XIX stoljeća, njihovo ušće bilo je tridesetak kilometara zapadnije, kod Osijeka. Do tada plovidba većih brodova do Osijeka prije regulacija Dunava i Drave nije bila nimalo laka 
Apatin je luka osječke komande i skladište baruta, olovnih zrna, dvopeka, usoljene ribe i mesa i drugih namirnice potrebnih vojsci, osobito lijekova i sanitetskoga materijala. Lijekovi su nabavljani diljem svijeta i dopremani Dunavom do Apatina odmah po habsburškom osvajanju ovoga dijela Podunavlja, odakle su ljekovito bilje, sirovine za preparate (najskuplje su bile tinkture i ini ekstrakti napravljeni u manufakturnim radnjama Beča i drugih farmaceutskih središta) i lijekove distribuirali preko Osijeka za vojne ljekarne u pukovnijskim središtima i Brodu na Savi, a odatle po satnijskim ljekarnama - put brodom od Apatina do Osijeka zahtijevao je mnoge brodarske vještine zbog brojnih rukavaca, povremenih ada i ritova koje su ovisile o vodostaju ovih rijeka. Roba se skladištila u golemim drvenim halama, a nakon 1739 . godine skladišta se grade od opeke. Tada je rekonstruirano pristanište, sagrađena je vojarna, upravna zgrada pristaništa koje je otvoreno i za civilne brodove. Podignute su kuće za časnike i stanovi za lađare, ribare i vodiče konja, te konjušnice i skladišta hrane za konje. Duž Dunava od Beča pa sve do Apatina uređena je kopitnica - staza za uzvodnu konjsku vuču lađa, šajki i čamaca; lađe su uzvodno vukli i kmetovi, što je bila teška rabota i golem namet vlastelinstvima, kao i kažnjenici. Ubrzo su se u Apatin doselili trgovci, ribari, lađari i obrtnici potrebni za rad baze. Većina doseljenih su bili Nijemci, kolonizatori cara Karla VI. Godine 1748. počela je velika kameralna kolonizacija Nijemaca, a Apatin je proglašen vratima kolonizatora.

Vojna bolnica u Apatinu podignula je 1758. godine sredstvima Dvorske komore i bila je subordinirana osječkoj, petrovaradinskoj i pakračkoj (i iločkoj) vojnoj bolnici, a iz nje se nadzirao i rad stacionara u pukovnijskim središtima i u Brodu na Savi. $\mathrm{U}$ apatinskoj bolnici su radila tri liječnika i relativno brojno pomoćno medicinsko osoblje - u Apatinu još od 1749. godine rade dva ljekarnika i tri kirurga.

Petrovaradinska Vojna bolnica preseljena je s Lasa, gdje je koncem XVII stoljeća podignut golemi kompleks drvenih baraka za potrebe ratne bolnice, u petrovardinsku tvrđavu. Gradnja objekata na Lasu ne bi bila racionalna - udaljenost, skupoća, ... - pa je Josip II 1783. odredio da se dio petrovaradinskoga franjevačkoga samostana pretvori u Vojnu bolnicu. Godine 1786. uočio je Josip II vlastitu pogrešku i odredio da se cijeli franjevački samostan pretvori u Vojnu bolnicu, što je ostalo do danas. [9, $10,15,21,22]$

Stara Gradiška, Vinkovci i Srijemska Mitrovica bili su središta graničarskih pukovnija. Pukovnije su osnovane 1747. godine, a razvile su se iz ranijih krajiških upravnih struktura. Uz njih je od 1762. djelovao i Šajkaški bataljun u sastavu Du- 
navske flote. Sjedište šajkaša, dobro naoružanih i lako pokretljivih lađa, bilo je u Petrovaradinu. U središtima graničarskih pukovnija osnovani su medicinski stožeri, vojne ljekarne i stacionari s nekoliko kreveta - iz stacionara razvit će se u prvoj polovici XIX stoljeća vojne bolnice. Vojne vlasti odredili su da ljekarnici sami skupljaju ljekovito bilje i botaniziraju, tj. uzgajaju ljekovite biljke te izvode pokuse sa sadnjom biljaka. Istu obavezu imali su i satnijski liječnici, većinom kirurzi, koji su morali imati priručnu ljekarnu s lijekovima kako za hitne slučajeve tako i lijekovima i zavojnim materijalom za zahtjevnije zahvate. U Vojnoj krajini postojali su strogi propisi nadzora hrane i bunara te o čistoći okoliša i stanova, a nadzor nad izvršavanjem propisa imao je pukovnijski liječnik. Osobito je bila razvijena mrtvozornička služba. Svakoga pokojnika pregledala je stručna osoba. Bilo je zabranjeno ljubiti pokojnika, držati ga dugo u prostoriji u kojoj obitavaju njegovi ukućani i moralo ga se propisno ukopati. $[2,9,10,15,21,22]$

U kumpanjama ili satnijama djelovali su kirurzi i primalje. Osigurali su u kumpanijskom središtu prostor za stacionar i skladište za lijekove sigurno od vlage i zaštićeno od provala. Ako bi se pojavila kakva zaraza u ataru, bili su dužni izvještavati pukovnijski medicinski stožer svakih pet dana, a u razdobljima bez opasnosti epidemija izvješća su slali jednom tjedno. Slični propisi koji se tiču nadzora i izvještavanja vrijedili su i kod zaraza stoke. U stacionar bi smjestiti i oboljele od nepoznatih bolesti i svakodnevno izvještavali nadređene o zdravstvenom stanju oboljelih.

U Vojnoj krajini je nepozivanje primalje na porod bilo kažnjivo, a od 1818. godine je carskom odlukom bio zabranjeno na porod zvati seoske žene. Od 1859. godine plaćanje primalja i nadzor nad njihovim radom nemaju više vojne vlasti već su satnijske primalje u Vojnoj krajini postale općinske primalje s određenom godišnjom plaćom.

Ljekarne u satnijama nadzirao je jednom godišnje pukovnijski liječnik i izvješća slao središnjoj komadi, a liječnici u satnijama često su provjeravali stanje lijekova i uvjete u kojima se čuvaju preparati, lijekovi i prostorima u kojima se suši i pohranjuje ljekovito bilje. Priručne ljekarne satnijskih liječnika nadzirao je pukovnijski liječnik. Osobito su pazili na zgradu u kojoj je ljekarna (suhoća podruma i zidova, kvaliteta podova i zaštita od glodavaca i požara, čistoća tavanskih prostora na kojima se sušilo ljekovito bilje, opća higijena ljekarničkoga prostora), inventar ljekarne (ormari, posuđe, vage i utezi) te načine čuvanje snažnih lijekova i otrova. [2, 4, 7, 11, 23-27]

U satnijskim ljekarnama su imali lijekove protiv svraba (crni sapun i sumpor), ludila 
(sudorifera, purgativa, emetica, vesicatia, a ako antiphlogistička sredstva nisu pomogla, za nesretnika se govorilo da ga tišti nesretna ljubav protiv koje, naravno, nema lijeka), kuge (kamfor, valeriana), želučanih kiselina i srčanih bolesti, a na zalihi su imali i najfrekventnije veterinarske lijekove. Pravljenje preparata i lijekova bilo je određeno vojnim farmakopejama, koje je izdavala središnja vojna vlast. Ljekarnici su lijek smjeli izdati samo na recept pukovnijskoga liječnika, satnijskoga liječnika i drugih kirurga - ako je recept izdao kirurg-brijač, na receptu je morao biti potpis satnijskoga liječnika. Lijekove i praškove umatali su u stari papir i tako ih izdavali. Pomno su bilježili izdane lijekove u posebno čuvanim bilježnicama, koje su služile kao osnovica financijskoga obračuna i stanja zaliha u ljekarnama u satnijama. Premda su krajišnici imali prava na neke besplatne lijekove, rijetko su ih koristili uzdajući se u Božju providnost, zagovore svetaca i pučku farmakopeju. Unatoč otporu seljaka-vojnika, vlasti su poticale korištenje lijekova i afirmaciju akademske medicine. Krajišnicima je bilo zabranjeno nagrađivati liječnike i ljekarnike, a oboljelima na čardacima su liječnici morali dolaziti u pohode i donosili su propisane lijekove pri čemu su im često pomagali konjanici-überreiteri. Dopuštenje za osnivanje ljekarne davale je središnja vojna vlast (isprva Beč, kasnije Pešta, a od sredine XIX stoljeća Zagreb) nakon konzultacija s pukovnijskim liječnikom. U Vojnoj krajini postojale su u prvoj polovici XIX stoljeća:

- garnizonske ljekarne u središtima pukovnija,

- vojničke ljekarne u manjim mjestima i

- građanske ljekarne, koje su lijekove nabavljali za potrebe civila i (uz ugovore) vojnika.

Godine 1644. je car Ferdinand izdao Zakon o ljekarnama kojim su propisane cijene lijekova, uvjeti za stjecanje dozvole za rad ljekarnika i nadzor nad ljekarnama. Sastav i izrada lijekova propisani su Farmakopejom, službenim dokumentom, brižno uređenom i često revidiranim. Najstarija je bila u upotrebi od 1686. do 1770. godine. Godine 1774. izlazi prvo izdanje nove Farmakopeje za naše krajeve, koja je do 1794. godine doživjela pet izdanja.

Kada bi odlazili na ratišta diljem Europe, vojnici iz Vojne krajine imali su svoju zdravstvenu službu s potrebnim lijekovima, najčešće za ublažavanje bolova i stavljanje obloga te previjanja otvorenih rana. S mobiliziranim seljacima iz civilnoga dijela na bojišnicu išli su franjevci, kao duhovnici, ali i kao vidari. [2, 4, 7, 11, 23-26, 28] 
I u civilnim i u vojnim dijelovima Slavonije i Srijema ljekarnici su obavljali zadaće hitne medicinske skrbi. Dobro su prepoznavali akutna stanja, znali su prema njima reagirati i imali lijekove i preparate koje su davali pacijentima u tim stanjima. Tržište apotekarskih proizvoda uspostavljeno je nakon ukidanja isusovaca i prestanka franjevačkog angažmana u liječenju stanovništva. U drugoj polovici XVIII stoljeća trgovačka društva dobila su privilegij neplaćanja poreza na lijekove i počelo se u ljekarništvo širiti privatno poduzetništvo - vlasti su predale nabavku i opskrbu lijekova privatnicima i prestale obrazovati vojne ljekarnike koje do tada nisu dovoljno koristili. Do tada je o nabavci i distribuciji lijekova i sirovina za galenske preparate brinulo posebno vojno ravnateljstvo. Odmicanje povlaštenih staleža iz trgovine ljekovitim biljem i lijekovima, otvorilo je tržište i podignulo kakvoću farmaceutskih proizvoda i znatno im snizilo cijenu, učinilo ih dostupnim većini stanovništva te punilo državnu riznicu i budžete lokalnih vlasti. Ljekarnu je mogao otvoriti samo onaj svršeni farmaceut, koji je imao dovoljno novca za opremanje ljekarne i apotekarskih i skladišnih prostora te nabavku lijekova i sirovina za lijekove i preparate. [2, $4,7,11,23-27,29]$

Ljekarnik je morao imati kuću, vlastitu ili u najmu, propisanih dimenzija zaštićenu od vlage i provala. Kuća je morala imati odijeljeni ljekarnički (trgovački) i skladišni (apotekarski) prostor te prostor za pripremu preparata. Na zalihi je moralo biti raznih vrsta (i količina) lijekova i sirovina za galenske preparate, koje su propisale važeće farmakopeje; od ukupno 867 vrsta dopuštenih lijekova u Austrijskoj Carevini, godine 1854. u našim krajevima ljekarnici su morali na zalihi imati 396 lijekova, masti, prahova, čajeva, ulja, sirupa, tinktura i ekstrakata. Ljekarna je morala imati nekoliko vrsta vaga, utega, menzura, posuda, plamenika, hvataljki i drugih potrepština za pravljenje ekstrakata i tinktura.

Unatoč podjeli na civilni i vojni dio, vojarne su stajale u većim naseljima civilnoga dijela Slavonije i Srijema. Vojni objekti, skladišta, isturene posade i vojarne su bile u Vukovaru, Irigu, Valpovu, Virovitici, Požegi, Pakracu, a možda povremeno i još u nekim trgovištima i varošicama Virovitičke županije, Srijemske županije i Požeške županije. U vojarnama je stacionirano između 100 i 400 profesionalnih vojnika s vlastitom medicinskom infrastrukturom (kirurzi, kupalištarci, ljekarnici, veterinari), a vojska je za svoje potrebe u civilnom dijelu Slavonije i Srijema gradila priručne stacionare i vojne bolnice. [30, 31]

Zemun je kao i Brod na Savi i Srijemska Mitrovica bio slobodni graničarski komu- 
nitet od 1751. godine.U to je vrijeme kapetan Zemunske satnije bio Ivan Podgoračan, zagovornik napretka Zemuna i okolice. Sjajno su surađivale vojne i civilne vlasti, te uredi državne uprave (pošta, carina, ...), pa je Zemun ubrzo postao naselje obrtnika i trgovaca udruženih u čak 12 cehova, a već sredinom XVIII stoljeća osnivaju se manufakturne radionice, dvije kavane - bile su to prve kavane u ovom dijelu Podunavlja - a početkom XIX stoljeća i tvornice. Kada je 1739. godine ustanovljena granica na Savi između Osmanlijskoga Carstva i Habsburške Monarhije, osnovan je u Zemunu središnji granični prijelaz. [9, 10, 15, 21, 22]

Srijemska Mitrovica imala je najzamršeniji status od svih gradova Vojne krajine. U sastav Habsburške Monarhije ušla je nakon mira u Požarevcu 1718. godine i priključena je feudalnim posjedima. Godine 1745. izdvojena je iz vlastelinstva obitelji Pejačević i pripojena Vojnoj krajini. Od 1747. godine je sjedište Petrovaradinske pukovnije, premda su neke pukovnijske službe ostale u Petrovaradinu. Srijemska Mitrovica je 1765. godine, kao i Brod na Savi, proglašena slobodnim graničarskim komunitetom i civilne su strukture osnažile i dobrim se dijelom nametnule vojnim upravnim strukturama (vojni komuniteti bili su i Petrovaradin, Srijemski Karlovci, Zemun i Brod na Savi). Osnivanje mitrovačkoga kontumca, jednog od četiri najvažnija na savskoj granici, potaknulo je naseljavanje trgovaca i obrtnika iz cijele Monarhije slobodnije nego u bilo koji drugi krajiški grad pa se na ovom području sreću različiti pristupi zdravlju i liječenju. No, pretvaranje kontumca u rastel (1777) usporio je razvoj Srijemske Mitrovice i umjesto grada trgovaca i obrtnika, Mitrovica se pretvara u grad vojnika-seljaka. Godine 1806. osnovana je civilna ljekarna, koja je, vjerojatno, odmah objedinila i vojnu ljekarnu, koja je bila u Srijemskoj Mitrovici od osnutka Pukovnije. $[9,10,15,21,22]$

Brod na Savi je izuzet iz uprave Brodske pukovnije i podređen izravno (osječkoj, a kasnije petrovaradinskoj) Slavonskoj generalkomandi - Brod je bio slobodni vojni komunitet i njim su upravljali nadkapetan i vojvoda; nadkapetana su postavljale vojne strukture, a vojvodu birali predstavnici građana. Prvi stanovnici postturskoga Broda bili su vojnici, koji su radili na obnovi srednjovjekovne utvrde. Obnovu Broda vodio je franjevac Augustin Jarić (ili možda Jaharić), a kasnije je zapovjednik Broda postao pukovnik Mihovil Kyba. Godine 1716. nakratko Turci ponovno osvajaju Brod, a kako su pri povlačenju uništili brodsku utvrdu, gradi se od 1722. do 1741. današnja tvrđava, golema i impresivna - Brod je sredinom XVIII stoljeća bio možda i najbolje utvrđeni grad na razmeđu habsburške i osmanlijske sfere, a smještajni kapacitet kretao se oko 4000 do 5000 stacioniranih vojnika. Tvrđava je imala golema 
skladišta hrane, vlastite pekare, klaonicu i mesnice, no unatoč dobro organiziranoj opskrbi vojnih potrepština, vojska je svejedno bila veliki potrošač dobara koje proizvode civili, što se osobito isplatilo brodskim trgovcima i obrtnicima, ali i seljacima iz okolice. Približno 2500 vojnika bilo je 1762. godine koncentrirano u tvrđavi i okolnim stražarnicama i potrebovale su mnoge pomoćne službe i uzrokovale naseljavanje u podgrađe brodske utvrde trgovaca, gostioničara i raznih obrtnika. [32-34]

Brodska Vojna bolnica i ljekarna osnovane su početkom XVIII stoljeća i bile su u staroj brodskoj tvrđavi. Civili su po pitanjima zdravstva bili prepušteni sami sebi. Unutar nove tvrđavske cjeline sagrađena je Vojna bolnica koja je imala 25 kreveta, ljekarnu i mrtvačnicu. U njoj su se mogli liječiti i civili, ako su namirili troškove lijekova i liječenja. [32-34]

O vremenu osnutka, djelovanju i ustrojstvu Vojne bolnice u Pakracu tako malo znamo, valjda stoga što se nije nalazila na području Vojne krajine već u Požeškoj županiji. Možemo pretpostaviti da je bolnica ostatak ratne infrastrukture iz 1737. godine, ili još ranijih ratova, a možda je bila smještena u srednjovjekovnoj utvrdi ili u njenoj neposrednoj blizini ili negdje uz rijeku Pakru - isto tako, moguće je da je bila na više lokacija i da je tijekom pola vijeka mijenjala lokacije na području današnjega Pakraca. Nije čudo što je 1754. godine bila u lošem stanju i da su županijske vlasti razmišljale preselili je u Požegu, zajedno s liječnikom i kapelanom. No, unatoč svim nedostacima, pakračka Vojna bolnica uspjela je usporiti razvoj medicinske infrastrukture Gradiške pukovnije u čijem je zaleđu bila. Vjerojatno je demobilizirana i u drugoj polovici XVIII stoljeća se utopila u Bolnici za stidne i kužne bolesti u Pakracu. $[8,16]$

Bolnica za stidne i kužne bolesti u Pakracu osnovana je u drugoj polovici XVIII stoljeća. Grof Antun Janković darovao je, svakako ne prije 1770. godine dok nije dovršena obnova, nekadašnji dvorac baruna Trenka da bi u njemu bila bolnica za liječenje veneričnih bolesti, koje su tada harale Slavonijom i Srijemom. Nedaleko Pakraca izbija jodna mineralna voda koja, tvrdila je onodobna stručna javnost, pomaže pri liječenju sifilisa i izvrsna je nadopuna lijekovima za liječenje različitih urogenitalnih i spolnih bolesti kod muškaraca i žena. Uobičajilo se okriviti baruna Trenka i njegove pandure za mnoge nevolje pa tako i za prenošenje spolnih bolesti u Slavoniju, osobito u Pakrac i okolicu te Požeštinu, što bi tek trebalo istražiti.

Termalna lipička voda smirivala je upale zglobova, uha, oka i upalne promjene na koži, ubrzavala je zacjeljivanje rana nakon ozljede ili operacije, a njezinim pijen- 
jem pojačavao se tek i jačao organizam. Bila je nadaleko poznata po blagotvornim učincima na oboljele od spolnih bolesti, osobito sifilisa, pa su oboljele slali u pakračku bolnicu i lipičke kupke na liječenje i oporavak. Isprva, naravno, pacijente iz okolice, ubrzo po osnivanju pakračke bolnice oboljele iz cijele Slavonije i Srijema, i civile i vojnike, a kada se lipička voda afirmirala, na liječenje su dolazili viši slojevi iz cijele Monarhije pa i velikodostojnici bečkoga dvora. $[8,16]$

U Daruvaru je grof Janković za bolesne vojnike, koje se ovamo na rehabilitaciju šalju iz čitave Slavonije, sagradio vojarnu. [8,16] Vojnu bolnicu u Iloku pratimo od 1784. godine, no s pravom možemo pretpostaviti da je osnovana puno prije ucrtavanja na plan grada Iloka. Nalazila se, vjerojatno, u istočnom dijelu Donjega grada duž ceste koja vodi prema Neštinu, gdje je stajao turski saraj. Godine 1794. vojne su vlasti tražile da se podigne vojna bolnica u Rumi, ili barem stacionar, da se oboljele ne prebacuje čak do Iloka, na što se oglušila Srijemska županija. [9, 10, 15, 30, 31]

Higijenom slavonskih i srijemskih krajiških naselja vlast se počinje baviti sredinom XVIII stoljeća. Uvode sanitarne službe, ulice postaju čišće, trgovi se popločavaju, a pse-lutalice lovi živoderska služba. Strvinari zbrinjavaju životinjski otpad u klaonicama, zaduženi su za higijenu tržnica i zakapaju uginulu stoku. Svaku sumnjivu uginulu životinju dužni su prijaviti najbližem kirurgu ili doktoru medicine. Noćobdije su odgovorne za protupožarnu zaštitu, kopaju se bunari, a vlasti potiču otvaranje javnih kupaonica. Isušuju se močvare. Premošćuju se potoci i rječice, grade se skele na velikim rijekama, obnavljaju se trase rimskih putova, koji sada postaju široki drumovi, uz koje se (postupno i uz prisilu) preseljava većina stanovnika. Naselja se grade planski, groblja se preseljavaju izvan naselja, propisuje se položaj stambenih objekata i bunara prema gnojnici, stajama, oborima i zahodu. $[8,5]$

Vojska je morala biti sita, sigurna, zdrava i jeftina, zaštićena od nepotrebne invalidnosti i prijevremene smrti što je moglo biti samo uz vrsnu liječničku i ljekarničku službu. Kako bi to postigli, organizirali su zdravstvenu zaštitu seljaka-vojnika u pukovnijama i satnijama i stacionarnih vojnika u vojarnama, ali i civila koji žive u Vojnoj krajini. Zamišljeno je da u središtu pukovnije djeluju dva vojna liječnika, a u središtima satnija kirurg-ranarnik (u prvoj polovici XIX stoljeća niži liječnik), no često su liječnička mjesta bila upražnjena pa su privremeno zapošljavani kirurziranarnici i patroni kirurgije. Slične modele primijenili su i u civilnim dijelovima Slavonije i Srijema, samo s puno manje liječnička a više kirurga. $[4,5,8]$

Socijalna zaštita Vojne krajine prebačena je na proširenu obitelj. Po uzoru na mili- 
tarnu društvenu organizaciju Pruske, poticalo se seljake da žive u kućnim zadrugama. Uobičajilo se u historiografiji povezivati krajiške kućne zadruge s tradicijskim oblicima obiteljskoga života Slavena, što svakako mora doživjeti povijesnu reviziju jer demografija opovrgava narativna vrela, na kojima se bazira stav starije historiografije. Sredinom XVIII stoljeća u civilnim dijelovima Slavonije svega oko 4,5\% seljaka živi u proširenim obiteljima, u drugoj polovici istoga stoljeća oko 10\%, a sredinom XIX stoljeća i približno 25\% obitelji živi u zadrugama, dok većina stanovnika živi u obiteljima do 10 članova poredanih u rodbinskoj vertikali rijetko većoj od tri generacije. U Baranji u prvoj polovici XVIII stoljeća u proširenim obiteljima živi oko $8 \%$ stanovništva, od toga u obiteljima s četiri i više odraslih bračnih parova živi približno 1,8\% stanovnika. Zadruge su skrbile o ranjenicima, invalidima, udovicama i djeci bez roditelja, a to se moglo samo ako je unutar kuće živjela proširena obitelj. $\mathrm{Na}$ ovom mestu možemo citirati zapis Artura Evansa iz 1875. „... ovdje je svaka zajednica neka vrsta dobrovoljnog društva; zajednički dom je samo azil za stare, bolnica za bolesne; u doba rata nije beznačajna korist Vojne granice, gdje je svaka kućna zajednica obrazovala bolnicu za onesposobljene vojnike te zajednice..."

Nadzor nad životom seljaka-vojnika bio je lakši u koliko je postojala odgovorna osoba. Za ne pozivanje primalje na porod, kućni starješina plaćao je u drugoj polovici XVIII stoljeća 2 forinte, što je bio za seljake golem iznos. Zbog grijeha ukućana nerijetko se batinalo kućnog starješinu, koji je nakon surove kazne strogo nadzirao ponašanja svojih ukućana. Obrtničke obitelji nisu bile brojne, svi su bili okupirani cjelodnevnim radom pa su oboljeli članovi obrtničkih obitelji odlazili u bolnicu na liječenje. Ceh je snosio troškove bolničkoga liječenja i oporavka članova obrtničkih obitelji, ali i šegrta, kalfi, siročadi i udovica svojih članova. Isto tako, vlastelinstva su snosile troškove bolničkoga liječenja za vlastelinske činovnike i članove njihovih obitelji i to kao čin milosrđa, a ne obaveze. [2, 4, 5, 10, 12, 14, 15, 19, 20]

\section{Vojno zdravstvo}

Josefinium je akademija za više i niže vojne liječnike. Počela je s radom 1785/86. godine, a iz Medicinsko-kirurške jozefinske akademije izlazili su vojni liječnici, kirurzi-ranarnici i kupalištari. Po završetku petogodišnjega studija kandidati su branili disertaciju i dobivali titulu višeg vojnog liječnika, magistra za očne bolesti i porodništva te postajali pukovnijski liječnici i šefovi bolničkih odjela. Od 1827. godine kandidati koji su završili trogodišnji studij medicine dobivali su naziv niži vojni liječnik - do tada je obrazovanje nižib vojnih liječnika trajalo nešto kraće. Josefinom je 
organizirao veterinarsku edukaciju na nekoliko razina.

\section{Civilno zdravstvo}

Medicina se od druge polovice XVIII stoljeća studirala u Beču, Pešti i Pragu, a povremenih medicinskih učilišta bilo je Ugarskoj, Češkoj i Austriji; inozemni diplomanti morali su nostrificirati diplome. Kirurgija se vraća u okvire akademske medicine i već u prvoj polovici XIX stoljeća kirurške zahvate u bolnicama obavljaju samo svršeni liječnici. Studenti medicine polažu i kolegij iz veterinarske medicine, a nakon svršenog studiju humane medicine mogu specijalizirati veterinarsku medicinu na dvogodišnjem stručnom studiju.

Doktori medicine zaposleni u civilnim ustanovama i viši vojni liječnici i dalje prate zarazne bolesti ljudi i životinja i vodeće su osobe za unapređenje javnoga zdravstva u zoni svoje odgovornosti - pukovnije ili županije. Poput današnjih sudskih vještaka, procjenjuju rad tuženih medicinskih djelatnika. Osobito nadziru rad konjskih vidara. Organiziraju tečajeve i ispite za medicinske djelatnike, prate i vrednuju njihov rad i, dakako, pomažu oboljelima i ozlijeđenima.

\section{Tabela 1}

\begin{tabular}{|c|c|c|}
\hline Vojno zdravstvo & \multicolumn{2}{|c|}{ Civilno zdravstvo } \\
\hline Pukovnijski liječnik & \multicolumn{2}{|c|}{ Županijski fizik } \\
\hline Satnijski liječnik & \multicolumn{2}{|c|}{ Gradski/kotarski fizik } \\
\hline Patron kirurgije; kirurg-veterinar & \multicolumn{2}{|c|}{ Patron kirurgije; kirurg-veterinar } \\
\hline Kirurg-ranarnik & \multicolumn{2}{|c|}{ Kirurg ranarnik } \\
\hline Kirurg-brijač & \multicolumn{2}{|c|}{ Kirurg-brijač } \\
\hline Kovač koji vadi zube & \multicolumn{2}{|c|}{ Kovač koji vadi zube } \\
\hline Redovnički & $\begin{array}{c}\text { Franjevci - Brod } \\
\text { Kirurzi }\end{array}$ & na Savi, Ruma, \\
Zemun & kirurzi & $\begin{array}{c}\text { Isusovci - Požega (javno } \\
\text { djelovanje) }\end{array}$ \\
\cline { 2 - 3 } & & $\begin{array}{c}\text { Franjevci - Virovitica } \\
\text { (javno djelovanje), } \\
\text { Našice, Osijek, Vukovar, } \\
\text { Šarengrad (?), Ilok }\end{array}$ \\
\hline \multicolumn{2}{|c|}{ Primalje } & \multicolumn{2}{c|}{ Primalje } \\
\hline
\end{tabular}




\begin{tabular}{|c|c|c|c|}
\hline \multirow[t]{4}{*}{ Ljekarnici } & $\begin{array}{c}\text { Vojni - Brod na } \\
\text { Savi, Vinkovci, } \\
\text { Petrovaradin, } \\
\text { Srijemska } \\
\text { Mitrovica } \\
\end{array}$ & \multirow[t]{4}{*}{ Ljekarnici } & Vojni-Osijek \\
\hline & $\begin{array}{c}\text { Civilni - } \\
\text { Petrovaradin }\end{array}$ & & Civilni - Osijek \\
\hline & $\begin{array}{c}\text { Redovnici- } \\
\text { franjevci } \\
- \text { Zemun (javno } \\
\text { djelovanje ?), }\end{array}$ & & $\begin{array}{c}\text { Redovnici-franjevci } \\
\text { - Virovitica, Našice, } \\
\text { Osijek, Vukovar, } \\
\text { Šarengrad (?), Ilok }\end{array}$ \\
\hline & Brod na Savi & & $\begin{array}{c}\text { Redovnici-isusovci } \\
\text { - Požega (javno } \\
\text { djelovanje) }\end{array}$ \\
\hline & & & \\
\hline
\end{tabular}

Pukovnijski liječnik (Stabsarzt) i kirurzi raznih profila bili su najvažniji medicinski djelatnici u pukovnijama. Najviše obrazovan medicinski djelatnik bio je pukovnijski liječnik, no to nije nužno značilo da je i doktor medicine.

Obrazovanje djelatnika veterinarske medicine počelo je sredinom XVIII stoljeća na austrijskim medicinskim učilištima kao dopunski studij doktora medicine. Niži vojni liječnici, viši vojni liječnici i doktori medicine mogli su kroz cijelo XVIII stoljeće nastaviti dvogodišnji stručni poslijediplomski studij veterinarske medicine i obavljati najviše vojne i civilne veterinarske službe. Srednji medicinski djelatnici, kirurzi-brijači i kirurzi-ranarnici, mogli su polagati ispiti iz veterinarske medicine i zapošljavati se na vojnim i civilnim veterinarskim poslovima. Bilo je kirurga-ranarnika koji su nastavili studirali medicinu na vojnom učilištu i njih zovemo patronima kirurgije i porodništva. Ako su položili ispite i iz veterinarske medicine, nosili su titulu kirurga-veterinara i mogli su obnašati više vojne i civilne veterinarske službe.

Konjski vidari bili su prvi akademski obrazovani liječnici veterinarske medicine koji nisu studirali humanu medicinu već samo veterinu, tj. nakon polaganja ispita za kirurga-ranarnika studirali su dvije godine veterinu. Živinar-veterinar je nakon gimnazijske male mature studirao u prvoj polovici XIX stoljeća veterinarsku medicinu na vojnom učilištu dvije godine, a u drugoj polovici XIX stoljeća studij je trajao 
tri godine. Nakon diplomiranja su nadzirali su rad veterinarskih radnika - konjskih vidara, kirurga-veterinara, kirurga-ranarnika, kirurga-brijača i kuršmida; kovačkuršmid je bio pomoćnik srednjim i višim veterinarskim djelatnicima. Na prijedlog kirurga-ranarnika s položenim veterinarskim ispitom su kovači posebno vješti u potkivanju konja odlazili početkom XIX stoljeća na šestomjesečni tečaj na vojno medicinsko učilište. Nakon tečaja su pred posebnom komisijom koju je predvodio pukovnijski liječnik polagali poseban ispit i dobivali zvanje kuršmida. [36] Überreiter (jahač) je bio isluženi narednik ili koji drugi niži časnik, koji je na konju obavljao hitnu ambulantnu službu u kompaniji i raznosio lijekove oboljelima.

Franjevce su nerijetko mobilizirali za pohode kao duhovnike, ali i kirurge i ljekarnike, što je franjevcima otvaralo mogućnost izučavanja ratnih rana $\mathrm{i}$ novih kirurških tehnika te provjeravanja kakvoće pojedinih preparata. U vojsci su dobro izučili zanat, primali savjete od iskusnih i obrazovanih kirurga-ranarnika i doktora medicine, a na bojišnici podlijegali kontroli svoga rada. Svakoga petka u 11 sati zvoni petrovaradinska crkva Svetoga Roka u spomen na pobjedu Eugena Savojskog 5. kolovoza 1716. godine protiv Damad Ali-paše kod Tekija pored Petrovaradina. Vrela navode da je pored tekijske kapele održana 8. kolovoza misa zahvalnica za pobjedu nad osmanlijskom vojskom koju su služila 74 vojna svećenika (dijecezanski svećenici, isusovci, franjevci, karmelićani, augustinci i ostali redovnici), koji su prije bitke obavljali dušobrižničku službu, a nakon bitke pomagali ranjenicima.

Obogaćeni takvim iskustvima oplemenili su slavonsku medicinu praktičnim savjetima kirurzima-brijačima i kirurzima-ranarnicima, a obavljali su i sami kirurške zahvate, pa i u području abdomena. Zasluga je franjevaca što racionalni postupci ulaze u praksu pučke medicine. Nesebično dijeleći iskustva što su ih stekli na bojišnicama i znanja koja su stekli obrazovanjem, u praksu tradicionalnoga liječenja unose nove tvari i postupke, koji su u pravilu racionalni i djelotvorni, te potiskuju stare postupke galenske i srednjovjekovne medicine. Donosili su s bojišnice kirurška pomagala i ine medicinske alatke poput stomatoloških kliješta, a sa samostanskim majstorima ih i sami izrađivali te prodavali ili dijelili. $[6,8,12,14-18,20]$

Godine 1788. u cernički franjevački samostan je smještena vojna bolnica, a nešto kasnije i u požeški samostan. Naredne godine pojavila se među ranjenicima zaraza od koje je umrlo 8 cerničkih franjevaca, a u Požegi su umrla dva redovnika. Naime, car Josip II uvukao je Habsburšku Monarhiju u još jedan Dubički rat protiv Turaka kako bi pomogao ruskoj carici Katarini da protjera Osmanlije iz Europe, koji su 
nastavili njegovi nasljednici i u kojem nije bilo značajnijih teritorijalnih pomaka. [8, 16] Franjevci su napustili Požegu 1789. godine i u nju se vratili iz Velike već 1796. godine. Za to je vrijeme u samostanu bila vojna bolnica, a crkva Svetoga Duha je desakralizirana i služila je kao skladište. $[8,16]$

Početak XIX stoljeća obilježili su ratovi protiv Francuza. Kako bi se zaustavilo širenje ideja Francuske revolucije, a kada je u protuudaru Napoleon zaprijetio rušenju Monarhije, prebacio je bečki dvor krunu, dragocjenosti i riznicu u Osijek i Petrovaradin - ispod petrovaradinske utvrde iskopano je čak 16 kilometara tunela. Bečka monarhija trpjela je od Napoleona brojne udare i bila prisiljena na znatne teritorijalne ustupke pa je odgovorila pregrupiranjem trupa i gradnjom bolničkih prostora u sigurnijim područjima. Regimenta Erdödy uselila se u prostorije konjičke vojarne u Virovitici i otvorila je 1805. godine bolnicu. Ubrzo je prostore preuzela regimenta Vincent, koja je između 1809. i 1812. godine sagradila golemu virovitičku vojarnu. Prestankom ratova bolnica nije ugašena već je teret održavanja bolnice spušten na gradski magistrat pa su godine 1825. Virovitičani tražili da se Vojna bolnica iseli iz njihovoga grada zbog ogromnih troškova. Međutim, vojne vlasti su imale drugačije planove - sagraditi Divizijsku bolnicu u Virovitici. Bolnica je dovršena 1838. godine, koja nije bila Virovitičanima na trošku, ali se u njoj nisu liječili Virovitičani. Godine 1849. Divizijska bolnica postala je vojni rehabilitacioni centar. $[1,5]$

Vojna bolnica između Bilja, Kneževa i Vardarca sagrađena je vjerojatno za vrijeme vladavine Josipa II, no u punoj je funkciji bila za vrijeme ratova protiv Napoleona i kao bolnica i kao logor za zarobljene francuske vojnike. Od početka XIX stoljeća u Dardi djeluje ljekarna, no na žalost mnogi baranjski medikohistorijski procesi još uvijek nisu ušli u fokus hrvatske historiografije. [11]

Uspon Zemuna, Srijemske Mitrovice i cijeloga Srijema posljedica je živahne trgovine sa Srbijom u koji se obogatio trgovačko-stočarski sloj nakon što je vlast učvrstio Miloš Obrenović. Miloš i vladari nakon njega su priznavali suverenitet Osmanlijskoga Carstva, no taj se suverenitet sve slabije osjećao. Splet pozitivnih povijesnih okolnosti i odlučna volja (uz mnoge žrtve) Srba za neovisnošću oslobodili su Kneževinu Srbiju osmanlijske vlasti. [9, 10, 15, 21, 22]

Uspon Broda na Savi omogućili su isti razlozi - uspostava Miloševe vlasti u Srbiji. Trgovci Turci, Cincari, Vlasi, Bugari, Grci, Makedonci zaobilazili su Beograd i preusmjerili su trgovačke putove prema graničnom prijelazu kod Broda na Savi. [32-34] 
Gašenje središnje Vojne bolnice u Apatinu - u prvoj polovici XIX stoljeća preseljena je apatinska Vojna bolnica u Sombor - potaknulo je gradnju bolničke infrastrukture u Novoj Gradiški, Vinkovcima, Srijemskoj Mitrovici i Zemunu te u Osijeku, Petrovaradinu i Slavonskom Brodu, ali i u civilnim dijelovima Slavonije i Srijema. Nakon što su obrazovali dovoljan broj liječnika i srednjeg medicinskog osoblja, vlasti su u prvoj polovici XIX stoljeća potaknule osnivanje mreže bolnica u Vojnoj krajini. Gradnja bolnica nije opteretila državnu riznicu jer je središnja vlast troškove gradnje i održavanja bolnica u cijelosti prebacila na budžete ambijentalnih vlasti što je dodatnim porezima opteretilo lokalno stanovništvo pa su i civili koji žive Vojnoj krajini dobili pravo liječenja u vojnim bolnicama.

Bolnica u Srijemskoj Mitrovici počela je s radom 1826. godine, a blagoslovio ju je mitrovački župnik Stanić, agilni svećenik i generator mnogih modernizacijskih procesa u Srijemskoj Mitrovici. Odmah je počela primati i građanstvo pa je dogradnja drvenih paviljona počela već naredne godine. Narednih desetljeća nastao je bolnički kompleks drvenih baraka i paviljona.

Premda je postojala potreba za bolnicom u Vinkovcima, nije bilo sredstava za njenu izgradnju i održavanje te plaće osoblja. Pokušaji da se dragovoljnim prilozima prikupe potrebna sredstva su propali, sve do 1831. godine, kada je u prizemlju Pukovnijskoga zatvora otvorena bolnica s 12 kreveta u tri sobe, a pored nje je bila i pukovnijska ljekarna.

Brodska Vojna bolnica sagrađena je u sklopu gradnje brodske tvrđave i imala je 25 kreveta u 12 nadsvođenih komora u bedemima tvrđe (u južnom krilu lijevog kavalira), kako samo ime kaže, kazamata, tamnih, mračnih prostora. U istom sklopu nalazila se i ljekarna, kupaonica, praonica i mrtvačnica. Približno 100 godina nisu se povećavali bolnički kapaciteti pa 1834. godine prostori bolnice nisu bili dovoljni ni za liječenje vojske, a kamoli civila. Od 19. svibnja 1835. godine brodska Vojna bolnica prihvaća sve bolesnike brodskoga komuniteta, a troškove održavanja bolnice preuzimaju, uz vojsku, i karitativne udruge, gradski magistrat i snažni pojedinci koji žive u Brodu i okolici.

Bolnica u Novoj Gradiški osnovana je 1846. godine kako bi bila bolnica Gradiške pukovnije, a otvorena je u ranije napravljenoj zgradi, koja je oblikom, pozicijom i smještajnim kapacitetima (76 kreveta), te pomoćnim zgradama odgovarala onodobnim vojnim bolnicama. U njoj su radili kirurzi i vojni liječnici, a prvi doktor medicine u Novu Gradišku došao je 1873. godine. 
Petrovaradin je sredinom XIX stoljeća imao tri bolnice - golemi lazaret na Lasu, suvremenu vojnu bolnicu u prostorima nekadašnjeg franjevačkoga samostana te Građansku bolnicu osnovanu 1848. godine na Starom Majuru, petrovaradinskom podgrađu, sagrađena u vrijeme haranja kolere.

U civilnim dijelovima Slavonije i Srijema bolnice organiziraju vjerske udruge, bratovštine, nošene filantropskim nakanama te plemići i gradske elite, a vojne bolnice u civilnim dijelovima Srijema i Slavonije (Virovitica, Vukovar, Osijek, Ilok, ...) ostaju u nadležnosti i pod patronatom središnjih vlasti i u njima se ne liječe civili, pa ni plemići ni redovnici. Rad bolnice organizirao je pukovnijski liječnik, a uz njega je u bolnici radio i sekundarni liječnik, često i sam doktor medicine ili viši vojni liječnik. O kuhinju i rublju bolesnika obično je brinula ravnateljeva supruga, koja je imala pomoćnicu. Srednje i niže poslove obavljali su patroni kirurgije, kirurziranarnici i bolničari, koji su bili plaćeni za svoj rad. Troškove hrane i lijekova snosile za oboljele časnike i vojnike vojne vlasti, obrtnicima i članovima njihovih obitelji te šegrtima i kalfama liječenje je plaćao ceh, poduzetnici svojim radnicima, obitelji za svoje članove, a općine za siromašne. Svaka je bolnica imala ekonomiju (oranice, livade, vrt te organiziran uzgoj životinja) iz koje je dobivala hranu za oboljele i osoblje. Obnove, osuvremenjivanja i dogradnje financirane su rijetkim dotacijama gradskih magistrata ili iz sredstava zaklada, oporuka, milodara i dobrovoljnih priloga iz crkvenih škrabica. [30-34]

U gradove, trgovišta i varošice na civilnom i vojnom području Slavonije i Srijema u drugoj polovici XVIII stoljeća i prvih desetljeća XIX stoljeća stizali su putujući liječnici i zubari, koji su naplaćivali usluge, ali i opsjenari i redikuli koji su koristeći moći uvjeravanja i jeftine trikove prodavali čudotvorne preparate (neškodljive vodice, prahove, gelove, ulja i masti), dijagnosticirali, masirali, mazali oboljele kojekakvim mastima i gelovima te vadili zube. Obično su pratili putujuće kazališne družine i cirkuse te svoje predstave organizirali na kirvajima i hodočasničkim mjestima i uopće na mjestima gdje se okuplja mnoštvo. Protiv njih su medicinski djelatnici često dizali tužbe. Od pohlepe za lakom zaradom nisu bili imuni ni vojni ranarnici, koji su pratili stacionarne trupe, koji su prodavali čudotvorne napitke koji liječe sve bolesti. [2, 4, 5, 10, 12, 14, 19, 20, 35]

Garnizonske ljekarne bile su u Novoj Gradiški, Vinkovcima i Srijemskoj Mitrovici, vojne bolničke ljekarne u Osijeku, Slavonskom Brodu i Petrovaradinu, a u središtima kumpanija priručne ljekarne s osnovnim lijekovima. Osječka vojna ljekarna brinula je 
o opskrbi lijekovima vojske u Novogradiškoj, Brodskoj i Petrovaradinskoj pukovniji - ne znamo gdje se nalazila prva vinkovačka vojna ljekarna; sigurno znamo da je bila uz stacionar, no još uvijek nismo detektirali gdje se nalazilo središte vojnoga zdravstva u Vinkovcima od sredine XVIII stoljeća pa do formiranja bolnice 1831. godine. U Vojnu krajinu se, kapilarno i uz otpor središnjih vlasti, naseljava civilno stanovništvo - obrtnici, trgovci, učitelji... [2, 4, 7, 11, 23-27]

Godine 1804. su privatizirane ljekarne u gradovima Vojne krajine, osim bolničkih ljekarni. Zakupci ljekarna morali su imati dovoljno lijekova za potrebe vojske i svakom su oboljelom vojniku morali izdati lijek, imao li on novaca ili ne. Kasnije su naplaćivali lijekove od graničara ili njegove obitelji ili od komande mjesta, što je nerijetko dovodilo do parnica. Vojnici su, naime, lijekove i pripravke dobivali besplatno ako su se ozlijedili ili razboljeli za vrijeme obavljanje službe, a polovicu cijene plaćali su ako su se razboljeli u slobodno vrijeme. Civili su plaćali punu cijenu lijeka. $[2,4,7,11,23-27]$

Skupljanje pijavica bio je monopol Vojne krajine. Pijavice su se izvozile u Francusku, a sakupljači su bili dužni određen broj pijavica predati pukovnijskim ili satnijskim medicinskim djelatnicima.

Vukovarska Vojna bolnica osnovana je 1849. godine. Naime, u svibnju te godine u Vukovar je došao ban Josip Jelačić s namjerom da prebaci trupe u Bačku. Hrvatske vojnike uhvatila je u Bačkoj kolera, od koje su umrla i tri vojna liječnika. U Vukovaru je na inicijativu bana Josipa Jelačića podignuta improvizirana drvena bolnica, koju je vodio Viktor Spitzer, kotarski liječnik u Vukovaru od 1845. godine. Za zasluge ga je pohvalio Josip Jelačić. [30, 31]

Vojna bolnica u Franjevačkom samostanu u Brodu na Savi (I) profunkcionirala je 22. kolovoza 1849. godine. Toga dana je u Brod stiglo približno 150 ranjenika iz Temišvara i Arada, koji su smješteni u devet prostorija i po hodniku. Bolnica je ugašena u prosincu iste godine ne zbog izlječenja bolesnih i ranjenih već zbog toga što je umro zapovjednik bolnice, ali i drugi bolnički ranarnik. Kroničar samostana bilježi da su franjevci nekoliko mjeseci trpjeli nesnosan smrad, koji je, očito, dolazio od ranjenika. [32-34] U Cerni oko 1850. godine djelovala je Graničarska bolnica za spolne bolesti, koje su uz alkoholizam, bile najveći zdravstveni problem Vojne krajine. [30, 31]

Vojna bolnica u Franjevačkom samostanu u Brodu na Savi (II) iz 1854. godine os- 
novana je odlukom Carsko-kraljevskog tvrđavskog zapovjedništva u Brodu. Franjevci su morali isprazniti zgradu u koju je vojska obijelila i postavila 500 bolničkih kreveta. U samostanu nije boravio ni jedan pacijent, a u jesen se bolnica iselila. [32-34]

Mnoge javnozdravstvene uredbe Vojne krajine pokazale su se učinkovitima pa su se higijenske (i druge) navade širile i u civilni dio Slavonije i Srijema. Pozitivne pomake u Vojnoj krajini zapazili su vođe zemalja u okruženja pa su primijenili krajiška iskustva na području pod svojom vlasti. Godine 1830. sultan je dozvolio otvaranje zdravstvenih ustanova, bolnica i ljekarni. Godine 1838. u Carigradu prvi put se na međunarodnoj konferenciji dogovaralo (i dogovorilo) oko suzbijanja kuge i kolere. Osmanlijsko Carstvo počelo je provoditi mjere kakve se provode u središnjoj Europi, a Austrija je kao pokazatelj podrške i povjerenja ukinula 1842. godine kontumac u Zemunu - reforme u osmanlijskoj medicini počele su 1827. godine kada se osniva novo medicinsko učilište po europskim uzusima, a koje vode osmanlijski liječnici obrazovani u Europi. Dostignuća europske medicinske znanosti primijenjena su i u azijskim i afričkim dijelovima Osmanlijskoga Carstva i naglo su se poboljšale epidemiološke prilike u Carstvu. Regulacije srednjega toka Dunava završene su 1828. godine, a naredne godine je Osmanlijsko Carstvo dopustilo promet Dunavom od Zemuna do Crnoga mora pa je Europa dobila još jedan međunarodni prometni koridor. Znatno je ojačala trgovina Dunavom pa je funkcioniranje Sanitarnoga kordona postalo bespredmetno. Internacionalizacija zdravstvene zaštite osobito se pojačala nakon 1851. godine nakon Međunarodna zdravstvena konferencija u Parizu te osnivanja Crvenog križa. [37]

Ukidanju Vojne krajine 1881. godine prethodilo je, dakle, nekoliko reformi Osmanlijskoga Carstva, koje su završile bankrotom (1875), da bi potom u Bosni i Hercegovini buknulo nekoliko međusobno nepovezanih ustanaka protiv središnje vlasti. Odluku da Austro-Ugarska Monarhija okupira Bosnu i Hercegovinu i ima suverenitet nad Kraljevinom Srbijom i Kneževinom Crnom Gorom donio je Berlinski kongres 1876. godine. Političari Banske Hrvatske tražili su od bečkih i peštanskih vlasti da se slavonski dio Vojne krajine pripoji slavonskim županijama i tako podredi vlasti Hrvatskoga sabora i bana. [1, 2, 4, 5, 10, 11, 14, 15, 19, 20, 35]

Umjesto zaključka: Vojna krajina ispunila je svrhu. Stvorila je animozitet prema Osmanlijskom Carstvu, vojno obrazovala seljake i koristila njihove potencijale na europskim ratištima, uvela intenzivnu poljoprivredu nasuprot ranije sakupljačke 
privrede s ekstenzivnim stočarstvom, a Sanitarni kordon je zaustavio širenje nekih epidemija. [37] Promijenjen je izgled sela, odijeljeni su prostori za život ljudi i prostori za život životinja, gnojnice i bunari su građeni na dovoljnoj udaljenosti, kuće su veće, prozračnije i s ostakljenim prozorima, a u prostorijama boravi manje ljudi nego prije. Podižu se u gradovima ubožnice sa siromašne, iznemogle i duševne bolesnike, te sirotišta i bolnice. U gradove Vojne krajine dolazi medicinsko osoblje (kirurzi raznih specijalnosti, farmaceuti) i vojni i civilni liječnici koji educiraju primalje. Otvaraju se škole, isprva na njemačkom jeziku, forsira se naseljavanje obrtnika i trgovaca, a uz djecu iz viših slojeva i staleža, obrazuju se i našijenci. Studiraju na učilištima diljem Monarhije i vraćaju se kao profesori, farmaceuti, pravnici, politehničari, liječnici i veterinari te uz ostale liječnike i druge medicinske djelatnike djeluju i prosvjetiteljski i kao pokretači društvenih i sportskih udruga i zaklada te šire pozitivno ozračje i u civilnim dijelovima Slavonije i Srijema.

\section{Reference:}

1. Beuc I. Povijest institucija državne vlasti Kraljevine Hrvatske, Slavonije i Dalmacije. Zagreb; 1995.

2. Bazala V. Poviestni razvoj medicine u hrvatskim zemljama. Zagreb; 1943.

3. Belicza B. Ranarnici u zdravstvenoj povijesti Hrvatske. Saopćenja (Pliva). 1973;16:213-223.

4. Belicza B. Zdravstvo i zdravstvene prilike Slavonije u 18. stoljeću. U: Čalić D, Berber Đ, urednici. Zbornik radova Peti znanstveni sabor Slavonije i Baranje; 1987 oktobar 22-23; Vinkovci. Osijek; 1991. 297-300.

5. Samaržija Z. Slavonija i Srijem. U: Vitale B, urednik. Četiri stoljeća javnog zdravstva i biomedicine u Hrvatskoj - Mala zemlja duge medicinske tradicije u globalnoj medicini 21. stoljeća. Zagreb; 2007.

6. Cvekan P. Virovitica i franjevci. Virovitica; 1977.

7. Fatović-Ferenčić S. Franjevačka ljekarna u Virovitici. U: Martinčić J, Hackenberger D, urednici. Zbornik radova Međunarodni simpozij 725 godina franjevaca u Virovitici; 2005 oktobar 17-19; Virovitica. Virovitica; 2006. 211-216.

8. Kempf J. Požega. Zemljopisne bilješke iz okoline i prilozi za povijest slob. i kr. grada Požege i Požeške županije. Požega; 1910.

9. Jeremić R. Prilozi istoriji zdravstvene kulture Jugoslavije i Balkanskoga 
poluostrva. Beograd; 1977.

10. Jovin S. Istorija medicine i zdravstvene kulture na tlu današnje Vojvodine 1718-1849. Novi Sad; 1998.

11. Bösendorfer J. Liječništvo i ljekarništvo u starom Osijeku. Jugoslavenska zastava. 1934;2:24.

12. Utvić V. Zdravstvo u Slavoniji do oslobođenja od Turaka. U: Čalić D, Berber Đ, urednici. Zbornik radova Peti znanstveni sabor Slavonije i Baranje; 1987 oktobar 22-23; Vinkovci. Osijek; 1991. 529-556.

13. Utvić V, Šenberger J. Zdravstvo u Osijeku u doba prosvijećenog apsolutizma. U: Roglić J, urednik. Zbornik radova Znanstvenoga skupa Osijek kao polarizacijsko žarište; 1980 travanj 10-12; Osijek. Osijek; 1981. 529-536.

14. Utvić V, Milošević B, Fališevac J. Razvoj medicine u Slavoniji - od prvih početaka do II svjetskog rata. U: Radauš V, urednik. Zbornik radova Prvi znanstveni sabor Slavonije i Baranje; 1970 maj 17-19; Osijek. Osijek; 1970. 529-556.

15. Jeremić R. Zdravstvene prilike u jugoslovenskim zemljama do kraja XIX veka. Zagreb; 1935.

16. Kern H. Jodna kupelj Lipik i njezine toplice. Zagreb; 1877.

17. Korade M. Doprinos isusovaca liječenju i razvoju medicine u Hrvatskoj u 17. i 18. stoljeću. Acta facultatis medicae fluminensis. 1992;3-4:193-206.

18. Mandić N. Znanstveni i edukativni pristup razvitku medicine u Osijeku. U: Roglić J, urednik. Zbornik radova znanstvenoga skupa Osijek kao polarizacijsko žarište; 1980 travanj 10-12; Osijek. Osijek; 1981. 523-528.

19. Thaller L. Povijest medicine u Hrvatskoj i Slavoniji od 1770. do 1850. Karlovac; 1927.

20. Thaller L. Zdravstvo Hrvatsko-slavonske vojne krajine. Lijec Vjesn. 1944;1:24.

21. Gavrilović S. Srem od kraja XVII do sredine XVIII veka. Novi Sad; 1979.

22. Jeremić R. Medicinske prilike u Zemunu. Beograd; 1937.

23. Grdinić V. Ljekarništvo na tlu Hrvatske: nasljeđe, vizije i ostvarenja. Zagreb; 1997.

24. Grdinić V. Ilustrirana povijest hrvatskog ljekarništva. Zagreb; 1997.

25. Mićić M. Osnivanje prvih apoteka u Sremu. Farmaceut. 1966;23:23-27.

26. Mićić M. Farmacija u Sremu 1758-1918. Novi Sad; 1987. 
27. Tartalja H. Kratki pregled povijesti farmacije. Zagreb; 1952.

28. Bazala V. Pregled povijesti zdravstvenog graditeljstva na području Socijalističke Republike Hrvatske - kulturno-historijski razvoj lječilišnih i zdravstvenih ustanova. Arhitektura. 1975;152/153:5-36.

29. Barbarić J, Šojat V. Zdravstveni izvještaji županijskih fizika Križevačke, Varaždinske, Virovitičke i Zagrebačke županije za 1785. godinu. Raspr Grada Povij Znan. 1989;5(1):104.

30. Dorn A. Prilozi poznavanju prošlosti zdravstvenih prilika u Vukovaru u 18. stoljeću. Lijec Vjesn. 1963;85:11-40.

31. Dorn A. Razvoj zdravstvenih ustanova u Vukovaru. U: Mihailović V, urednik. Medicinski centar Vukovar: razvoj zdravstva i medicinskih službi Vukovarske komune. Vukovar; 1976.

32. Kronika franjevačkoga samostana u Brodu na Savi I-IV. Slavonski Brod; 1995.

33. Balen I. Povijesni razvoj zdravstva u Slavonskom Brodu. U: Živaković-Kerže Z, urednik. Zbornik radova sa znanstvenog skupa u Slavonskom Brodu u povodu 750. obljetnice prvog pisanog spomena imena Brod; 1994 oktobar 13-15; Slavonski Brod. Slavonski Brod; 2002. 343-345.

34. Ilić T. Razvoj zdravstvenih prilika u Brodu do 1871. godine. U: Jelić A, urednik. Razvoj zdravstva na području općine Slavonski Brod. Slavonski Brod; 1975.

35. Maksimović J. Zdravstveno higijenske prilike u Vojvodini u XVIII i XIX veku i njihov uticaj na rađanje i odrastanje dece. U: Rađanje i odrastanje seoske dece u Vojvodini. Novi Sad; 2001.

36. Brozović L. Prilog povijesti veterinarstva u Hrvata. U: Topolnik E, urednik. Poseban otisak iz Spomenice Veterinarskog fakulteta Sveučilišta u Zagrebu 1919-1959. Zagreb; 1959. 97-122.

37. Utvić V, Čeović S. Nedoumice oko uspješnosti Sanitarnog kordona Vojne krajine u suzbijanju kuge. U: Čalić D, Berber Đ, urednici. Cetvrti znanstveni sabor Slavonije i Baranje; 1983 oktobar 26-28; Slavonska Požega, Zvečevo. Osijek 1984.680-696. 


\section{Summary}

The Military Frontier fulfilled its purpose. It had created animosity toward the Ottoman Empire; gave military training to farmers and used their potential on the European battlefields. Frontier introduced intensive agriculture instead of earlier foraging economy with extensive agriculture and stopped the spread of some epidemics by means of sanitary cordon. The Military Frontier changed the look of the villages by separating human and animal living space. Manures and wells were built at a sufficient distance, the houses were large, airy and with glass windows; in its rooms stayed fewer people than before. In the cities housing for the poor, infirm and mentally ill were build, as well as orphanages and hospitals. The cities of the Military Frontier attracted medical staff (surgeons of different specialties, pharmacists), and military and civilian doctors who educated midwives. Schools were opened, the settlement of craftsmen and traders was forced, and the children from the upper strata and classes, as well as scientists were educated. They studied at universities across the Habsburg Monarchy and returned as teachers, pharmacists, lawyers, polytechnicians, doctors and veterinarians. Along with other physicians and medical professionals they acted as founders of social and sporting associations and foundations, and helped improve the general atmosphere in civilian areas of Slavonia and Srem.

Poslat: 12.6. 2013.

Recenziran: 1. 8. 2013.

Prihvaćen: 7. 9. 2013. 